\title{
STUDI KOHORT PREVALENSI OBESITAS SISWA SISWI SEKOLAH LANJUTAN TINGKAT PERTAMA (SLTP) KOTA YOGYAKARTA
}

\author{
Emy Huriyati ${ }^{1}$
}

\begin{abstract}
Background: The prevalence of obesity is continuously increasing both in developed and developing countries. This increasing prevalence of obesity may be associated with the increasing exposure to obesogenic environment.

Objective: To know the trend of obesity prevalence among Rural Junior High School in Yogyakarta

Method: This cohort study was conducted in Yogyakarta at 2003 from August to October and at 2005 from June to September. Result: The prevalence of obesity in 2003 showed $7.3 \%$ and $10.3 \%$ in 2005. Thus, it increased 3\% during 2 years. But prevalence of obesity was not increased among 1440 students who followed body mass index percentile based on center for chronic disease (CDC) 2000.

Conclusion: During 2 years, the change of obesity status had not significantly shown because obesity occurred in a long period. While the increasing obesity prevalence occurred.
\end{abstract}

Key words: prevalence, obesity, BMI, Junior High School students

\section{PENDAHULUAN}

Penelitian ini bertujuan untuk mengetahui perubahan prevalensi obesitas yang terjadi pada siswa-siswi Sekolah Lanjutan Tingkat Pertama (SLTP) Kota Yogyakarta. Penelitian ini didasari oleh penelitian sebelumnya yang menunjukkan bahwa prevalensi gizi lebih sudah mulai terjadi pada siswa SLTP Kota Yogyakarta (1). Pengukuran status obesitas merupakan cara yang mudah dalam upaya pencegahan penyakit-penyakit degeneratif yang merupakan penyakit akibat kelebihan gizi (2). Penelitian ini diharapkan dapat memberikan informasi yang cukup akurat sebagai dasar penelitian obesitas pada masa mendatang di mana obesitas merupakan faktor risiko terhadap terjadinya penyakit degeneratif yang pada saat ini prevalensinya semakin meningkat.

Obesitas dalam dekade terakhir prevalensinya semakin meningkat di mana saja baik di negara maju maupun negara berkembang. Negara maju sekarang sudah menyadari bahwa faktor obesitas berperan terhadap terjadinya penyakit degeneratif sehingga upayaupaya untuk mencegah terjadinya obesitas sudah mulai dilakukan (3). Sementara negara berkembang seperti Indonesia saat ini bukan saja masih berkutat terhadap masalah kurang gizi tetapi dampak akibat gizi lebih atau obesitas sudah nampak pada sebagian rakyat Indonesia yang hidup berkecukupan tetapi dengan pola hidup yang salah sehingga hal inilah yang menyebabkan prevalensi obesitas di Indonesia semakin meningkat (4).

Penelitian ini diharapkan dapat memberikan manfaat bagi pembangunan negara terutama dalam hal peningkatan sumber daya manusia. Masalah obesitas kalau dibiarkan saja tentu akan sangat merugikan karena obesitas dapat menyebabkan penyakit degeneratif yang selain akan menurunkan produktivitas kinerjanya juga akan sangat membebani karena pengobatan penyakit degeneratif sangat mahal dan sulit untuk sembuh. Untuk itu semoga penelitian ini dapat memberikan informasi yang berharga terhadap penerapan ilmu pengetahuan terutama dalam upaya-upaya pencegahan penyakit degeneratif secara dini serta pencegahan obesitas yang merupakan faktor risikonya.

Pembangunan kesehatan diarahkan untuk meningkatkan kualitas sumber daya manusia, kualitas dan usia harapan hidup, meningkatkan kesejahteraan keluarga, serta mempertinggi kesadaran masyarakat akan pentingnya hidup sehat. Perbaikan gizi merupakan salah satu upaya untuk meningkatkan derajat kesehatan. Saat ini Indonesia menghadapi 2 masalah gizi sekaligus atau lebih dikenal dengan masalah gizi ganda, yaitu di satu pihak masalah gizi kurang masih menjadi masalah gizi utama di beberapa daerah dan lain pihak timbul masalah gizi lebih sebagai dampak dari peningkatan kemakmuran yang ternyata diikuti oleh perubahan gaya hidup. Masalah gizi kurang dapat meningkatkan risiko terhadap timbulnya penyakit infeksi sudah banyak ditanggulangi, sedangkan gizi lebih atau obesitas meningkatkan risiko terhadap timbulnya penyakit degeneratif seperti diabetes mellitus, penyakit jantung koroner, kanker, ginjal , hipertensi dan batu empedu (5) belum banyak ditangani.

Obesitas terjadi karena adanya ketidakseimbangan antara energi yang masuk dengan energi yang keluar. Banyaknya asupan energi dari konsumsi makanan yang dicerna melebihi energi yang digunakan untuk metabolisme dan aktivitas fisik sehari-hari. Kelebihan energi ini akan disimpan dalam bentuk lemak pada jaringan adipose (6). Obesitas dapat terjadi pada usia berapa pun. Menurut Dietz (7), terdapat 3 periode kritis dalam masa tumbuh

\footnotetext{
Program Studi S1 Gizi Kesehatan Fakultas Kedokteran UGM, Yogyakarta.
} 
kembang anak dalam kaitannya dengan terjadinya obesitas, yaitu: periode pranatal, terutama trimester 3 kehamilan, periode adiposity rebound pada usia 6-7 tahun dan periode adolesens. Menurut Taitz (8), 50\% remaja yang obesitas sudah mengalami obesitas sejak bayi. Pada bayi dan anak yang obesitas, sekitar $26,5 \%$ akan tetap obesitas untuk 2 dekade berikutnya dan $80 \%$ remaja yang obesitas akan menjadi dewasa yang obesitas (9). Penelitian di Jepang menunjukkan 1/3 dari anak obesitas tumbuh menjadi obesitas di masa dewasa (3). Obesitas akan menetap sampai dewasa apabila onsetnya terjadi pada akhir masa anak-anak atau remaja. Obesitas pada remaja menunjukkan hubungan yang bermakna dengan morbiditas dan mortalitas jangka panjang (3).

Prevalensi obesitas meningkat dari tahun ke tahun, baik di negara maju maupun negara berkembang. Prevalensi obesitas pada anak usia 6-17 tahun diAmerika Serikat dalam tiga dekade terakhir meningkat dari 7,6-10,8\% menjadi 13$14 \%$. Prevalensi obesitas pada anak usia 6-18 tahun di Rusia $6 \%$ dan $10 \%$, di Cina adalah $3,6 \%$ dan $3,4 \%$. Dan di Inggris adalah $22-31 \%$ dan $10-17 \%$, bergantung pada umur dan jenis kelamin (10). Di Thailand, prevalensi obesitas (BB/TB $>120 \%$ ) pada anak usia $6-12$ tahun meningkat dari $12,2 \%$ pada tahun 1991 menjadi 15,6\% pada tahun 1993 (3). Prevalensi obesitas pada anak-anak sekolah di Singapura meningkat dari $9 \%$ menjadi $19 \%$ (11).

Di Indonesia prevalensi obesitas juga meningkat, di DKI Jakarta prevalensi obesitas meningkat dengan bertambahnya umur. Pada umur 6-12 tahun ditemukan obesitas sekitar $4 \%$. Pada remaja umur 12-18 tahun ditemukan $6,2 \%$ dan pada umur 17-18 tahun sekitar $11,4 \%$. Kasus obesitas pada remaja lebih banyak ditemukan pada wanita $(10,2 \%)$ dibanding lelaki $(3,1 \%)$. Pada penelitian Djer dikutip Syarif (2) tahun 1998, prevalensi obesitas anak di sebuah Sekolah Dasar Negeri di kawasan Jakarta Timur sebesar $27,5 \%$. Penelitian Herini et al. (12) pada 30 sekolah dasar di Kota Yogyakarta ditemukan prevalensi obesitas pada siswa laki-laki $10,5 \%$ dan siswa perempuan $8,5 \%$ dengan rerata 9,5\%. Prevalensi obesitas tahun 1996 di 27 propinsi adalah 4,6\%. Menurut penelitian Susanti dikutip Syarif (2), prevalensi obesitas anak remaja di sebuah Sekolah Menengah Pertama (SMP) dan Sekolah Menengah Umum (SMU) swasta di Kota Bogor Kabupaten Jawa Barat sebesar $6,4 \%$. Prevalensi obesitas pada siswa SMU di Kota Tangerang sebesar 5,01\% (13).
Sulitnya mengatasi obesitas menyebabkan tatalaksana obesitas diutamakan pada usaha pencegahan, yang berarti diawali dari pencegahan obesitas pada masa anak dan remaja (2). Dengan demikian peneliti merasa perlu untuk mengetahui adakah perubahan prevalensi obesitas pada siswa SLTP di Kota Yogyakarta dalam kurun waktu 2 tahun.

\section{BAHAN DAN METODE}

Jenis penelitian ini adalah penelitian observasional dengan menggunakan rancangan kohort. Penelitian ini dilakukan di Kota Yogyakarta. Pemilihan lokasi didasarkan pada pertimbangan bahwa anak SLTP di wilayah tersebut sudah diukur antropometri pada tahun 2003. Waktu penelitian dilaksanakan pada bulan Juni sampai dengan Oktober 2005. Populasi penelitian ini adalah seluruh anak Sekolah Lanjutan Tingkat Pertama (SLTP) baik negeri maupun swasta di Kota Yogyakarta.

Sampel penelitian ini adalah anak SLTP di Kota Yogyakarta yang terpilih dan pernah diukur antropometri pada tahun 2003. Data didapat dari survei yang dilaksanakan di 6 SLTP Kota Yogyakarta. Untuk menghitung status obesitas diadakan pengukuran tinggi badan dan berat badan, serta perhitungan umur. Tinggi badan diukur menggunakan microtoise dengan tingkat ketelitian $0,1 \mathrm{~cm}$, sedangkan berat badan diukur dengan menggunakan timbangan injak digital merk sohnle dengan tingkat ketelitian $0,1 \mathrm{~kg}$. Perhitungan umur didasarkan selisih pencatatan tanggal pengukuran antropometri dengan tanggal lahir responden dalam tahun. Penilaian obesitas didasarkan kurva percentil $>95$ menurut Baku National Centre for Health Statistic (NCHS)/ Centre for Chronic Disease (CDC).

\section{HASIL DAN BAHASAN}

Dari hasil survei yang dilakukan di Kota Yogyakarta pada bulan Agustus sampai Oktober 2003 didapatkan prevalensi obesitas berdasarkan NCHS/CDC sebesar $7,3 \%$, atau 346 siswa-siswi mengalami obesitas dari 4747 siswa yang dilakukan pengukuran. Sedangkan pada bulan Juni sampai Agustus 2005 didapatkan prevalensi obesitas 10,3\% atau 482 siswa-siswi mengalami obesitas dari 4677 siswa yang dilakukan pengukuran seperti ditunjukkan pada Tabel 1. Hasil ini menunjukkan terjadinya kenaikan prevalensi sebesar $3 \%$ dalam jangka waktu 2 tahun. Sesuai

TABEL 1. Hasil survei pengukuran pengukuran body mass indeks (BMI) menurut umur berdasarkan CDC tahun 2000

\begin{tabular}{lccccc}
\hline $\begin{array}{l}\text { Tahun } \\
\text { survei }\end{array}$ & $\begin{array}{c}\text { Jumlah siswa } \\
\text { yang diukur }\end{array}$ & $\begin{array}{c}\text { Obesitas } \\
\text { > Percentile 95 }\end{array}$ & $\begin{array}{c}\text { Overweight } \\
\text { Percentile 85-95 }\end{array}$ & $\begin{array}{c}\text { Normal } \\
\text { Percentile 5-85 }\end{array}$ & $\begin{array}{c}\text { Kurang } \\
<\text { Percentile 5 }\end{array}$ \\
\hline 2003 & $346(7,3 \%)$ & $476(10,0 \%)$ & $3452(72,7 \%)$ & $473(10,0 \%)$ & $346(7,3 \%)$ \\
2005 & $482(10,3 \%)$ & $562(12,0 \%)$ & $3233(69,1 \%)$ & $400(8,6 \%)$ & $482(10,3 \%)$ \\
\hline
\end{tabular}


penelitian di banyak negara, prevalensi obesitas meningkat dari tahun ke tahun, baik di negara maju maupun negara berkembang (3).

Prevalensi ini lebih tinggi daripada penelitian Susanti dalam Syarif (2) bahwa prevalensi obesitas anak remaja di sebuah SMP dan SMU swasta di Bogor Jawa Barat sebesar $6,4 \%$. Hal ini terjadi karena perilaku kehidupan modern yang merujuk pada pola makan tinggi kalori, tinggi lemak dan kolesterol $(14,15,16)$, terutama terhadap penawaran makanan siap saji (fast food) yang berdampak meningkatkan risiko obesitas $(2,14,15,17)$ baik di daerah perkotaan maupun pinggiran kota, pada umumnya sekarang lebih disukai oleh remaja.

Selanjutnya dilakukan pengukuran pada siswa-siswi kelas 1 tahun 2003 dan pada saat mereka kelas 3 pada tahun 2005 diukur kembali. Sebanyak 1440 siswa yang dapat dilakukan pengukuran antropometri selama 2 kali pengukuran pada tahun 2003 dan 2005 (Tabel 2). keempat pengukuran antropometri tersebut. Kenaikan keempat pengukuran menunjukkan siswa-siswi tersebut mengalami pertumbuhan selama 2 tahun walaupun setiap siswa kenaikannya bervariasi.

Apabila dikelompokkan berdasarkan asal sekolah hasil pengukuran antropometri seperti pada Tabel 3 , pada tahun 2005 mean BB, TB, BMI dan BMIC tertinggi adalah pada SLTP Stella Duce. Hal ini juga sesuai penelitian tahun 2003 dan 2005 bahwa prevalensi obesitas tertinggi pada keenam sekolah adalah SLTP Stella Duce (Tabel 4).

Bila dibandingkan pada siswa yang diukur dua kali pada tahun 2003 dan 2005 jumlah anak yang obesitas berdasarkan hasil pengukuran BMIC menurut umur CDC tahun 2000 ternyata dalam kurun waktu 2 tahun tidak ada perubahan prevalensi obesitas atau perubahannya sangat kecil (Tabel 5). Hal ini sesuai dengan teori bahwa obesitas terjadi akibat ketidakseimbangan antara energi yang masuk dengan energi yang keluar dalam jangka

TABEL 2. Jumlah siswa-siswi yang diikuti pengukurannya selama 2 kali berdasarkan asal SLTP

\begin{tabular}{lccc}
\hline \multicolumn{1}{c}{ Nama SLTP } & $\begin{array}{c}\text { Jumlah siswa yang } \\
\text { diukur pada 2 kali } \\
\text { survei }\end{array}$ & Laki-laki & Perempuan \\
\hline SLTP N 1 & 236 & 121 & 115 \\
SLTP N 2 & 218 & 96 & 122 \\
SLTP N 5 & 350 & 172 & 178 \\
SLTP N 16 & 216 & 102 & 114 \\
SLTP Stella Duce & 221 & 107 & 114 \\
SLTP Muhammadiyah 2 & 199 & 94 & 105 \\
\hline Total & 1440 & 692 & 748 \\
\hline
\end{tabular}

Hasil pengukuran antropometri pada kedua survei menunjukkan 1440 siswa selama 2 tahun semua mengalami peningkatan mean (rata-rata) berat badan (BB), tinggi badan (TB), indeks massa tubuh/ body mass indeks (BMI), dan indeks massa tubuh/ body mass indeks percentile menurut centre for chronic disease (CDC) 2000 (BMIC). Hal ini ditandai peningkatan mean waktu yang lama. Banyaknya asupan energi dari konsumsi makanan yang dicerna melebihi energi yang digunakan untuk metabolisme dan aktivitas fisik seharihari. Kelebihan energi ini akan disimpan dalam bentuk lemak pada jaringan adipose (6).

Menurut Dietz (18), terdapat 3 periode kritis dalam masa tumbuh kembang anak dalam kaitannya dengan

TABEL 3. Hasil pengukuran antropometri pada kedua survei yang diikuti selama 2 tahun

\begin{tabular}{lcccccccc}
\hline \multirow{2}{*}{ Nama SLTP } & \multicolumn{2}{c}{ Mean BB $\mathbf{( k g )}$} & \multicolumn{2}{c}{ Mean TB $\mathbf{( c m})$} & \multicolumn{2}{c}{ Mean BMI } & \multicolumn{2}{c}{ Mean BMIC } \\
\cline { 2 - 9 } & $\mathbf{2 0 0 3}$ & $\mathbf{2 0 0 5}$ & $\mathbf{2 0 0 3}$ & $\mathbf{2 0 0 5}$ & $\mathbf{2 0 0 3}$ & $\mathbf{2 0 0 5}$ & $\mathbf{2 0 0 3}$ & $\mathbf{2 0 0 5}$ \\
\hline SLTP N 1 & 41.4 & 49,8 & 148,9 & 156,4 & 18,7 & 20,2 & 45,5 & 48,1 \\
SLTP N 2 & 40,4 & 47,7 & 147,6 & 155,3 & 18,4 & 19,7 & 44,6 & 44,7 \\
SLTP N 5 & 44,1 & 51,6 & 151,1 & 155,4 & 19,2 & 20,5 & 49,4 & 50,3 \\
SLTP N 16 & 39,2 & 46,7 & 147,9 & 155,0 & 17,8 & 19,3 & 35,9 & 40,7 \\
SLTP Stella Duce & 45,8 & 53,9 & 149,9 & 158,5 & 20,2 & 21,3 & 591 & 57,5 \\
SLTP Muhammadiyah 2 & 44,3 & 52,1 & 150,0 & 158,2 & 19,5 & 20,7 & 50,1 & 51,0 \\
\hline Total & 42,7 & 50,5 & 149,3 & 157,2 & 18,98 & 20,3 & 47,6 & 48,8 \\
\hline
\end{tabular}


Tabel 4 Prevalensi obesitas menurut umur CDC tahun 2000 berdasarkan sekolah

\begin{tabular}{lcc}
\hline \multirow{2}{*}{ Nama SLTP } & \multicolumn{2}{c}{ Jumlah obes } \\
\cline { 2 - 3 } & $\mathbf{2 0 0 3}$ & $\mathbf{2 0 0 5}$ \\
\hline SLTP N 1 & 17 & 19 \\
SLTP N 2 & 9 & 11 \\
SLTP N 5 & 28 & 25 \\
SLTP N 16 & 8 & 9 \\
SLTP Stella Duce & 31 & 28 \\
SLTP Muhammadiyah 2 & 25 & 26 \\
\hline Total & 118 & 118 \\
\hline
\end{tabular}

\section{KESIMPULAN DAN SARAN}

\section{Kesimpulan}

1. Prevalensi obesitas siswa SLTP Kota Yogyakarta mengalami peningkatan $3 \%$ dalam kurun waktu 2 tahun.

2. Terjadi perubahan peningkatan prevalensi obesitas tampak pada populasi yang lebih muda.

3. Perubahan status obesitas pada siswa-siswi yang diikuti selama 2 tahun sangat kecil.

TABEL 5. Perbandingan percentile pengukuran BMIC menurut umur CDC tahun 2000 selama 2 tahun

\begin{tabular}{cccccc}
\hline $\begin{array}{c}\text { Tahun } \\
\text { Survel }\end{array}$ & $\begin{array}{c}\text { Jumlah siswa } \\
\text { yang diukur }\end{array}$ & $\begin{array}{c}\text { Obesitas } \\
\mathbf{>} \text { Percentile 95 }\end{array}$ & $\begin{array}{c}\text { Overweight } \\
\text { Percentile 85-95 }\end{array}$ & $\begin{array}{c}\text { Normal } \\
\text { Percentile 5-85 }\end{array}$ & $\begin{array}{c}\text { Kurang } \\
\text { < Percentile 5 }\end{array}$ \\
\hline 2003 & 1440 & $118(8,2 \%)$ & $143(9,9 \%)$ & $1010(70,1 \%)$ & $169(11,7 \%)$ \\
2005 & 1440 & $118(8,2 \%)$ & $122(8,5 \%)$ & $1072(74,4 \%)$ & $128(8,9 \%)$ \\
\hline
\end{tabular}

terjadinya obesitas, yaitu: periode pranatal, terutama trimester 3 kehamilan, periode adiposity rebound pada usia $6-7$ tahun dan periode adolesens. Hasil penelitian ini menunjukkan bahwa perubahan prevalensi pada masa remaja yang diukur dalam kurun waktu 2 tahun tidak terjadi perubahan seperti terlihat pada Tabel 2. Hal ini sesuai dengan penelitian Taitz (8), bahwa 50\% remaja yang obesitas sudah mengalami obesitas sejak bayi. Jadi pada masa remaja sedikit perubahannya karena pada saat remaja kecepatan pertumbuhannya juga sangat pesat sehingga perubahan prevalensi kurang terlihat.

Hasil pengukuran $\mathrm{BMI}$ menurut umur pada kurva $\mathrm{CDC}$ tahun 2000 (BMIC) selama 2 tahun menunjukkan perubahan seperti ditunjukkan pada Tabel 6. Dari 1440 siswa yang diukur ternyata $819(56,9 \%)$ mengalami kenaikan BMIC sedangkan 620 (43,0\%) siswa nengalami

penurunan $\mathrm{BMIC}$ dan hanya seorang yang tidak mengalami perubahan BMIC-nya selama 2 tahun. Hal ini disebabkan karena kecepatan pertumbuhan pada masa puber yang sangat bervariasi.

\section{Saran}

1. Perlu penelitian lebih lanjut pada populasi yang lebih muda pada periode adiposity rebound saat usia 67 tahun sehingga perubahan status obesitas akan tampak karena saat itu kecepatan pertumbuhannya sangat rendah.

2. Pencegahan obesitas sebaiknya dimulai pada usia yang lebih dini karena status obesitas masih mudah diatasi sedangkan pada remaja akan lebih sulit.

\section{Ucapan Terima Kasih}

Penulis mengucapkan banyak terima kasih kepada Ketua Lembaga penelitian UGM, Dekan Fakultas Kedokteran UGM, Bapak Ketua Program Studi, sekaligus pembimbing penelitian ini Prof dr. Hamam Hadi, MS, Sc.D , Walikota Yogyakarta serta Kepala Kantor Dinas Pendidikan dan Pengajaran Kota Yogyakarta, Kepala Sekolah SLTP 1, 2, 5, 16, Stella Duce serta Muhammadiyah 2, Bapak ibu guru olahraga dan UKS serta siswa-siswi SLTP ke-6 sekolah tersebut. Berbagai pihak yang tidak dapat penulis sebutkan satu per satu yang telah membantu penelitian ini.

\section{RUJUKAN}

1. Mahdiah. Prevalensi Obesitas dan Hubungan Konsumsi Fast Food sebagai Faktor Risiko Obesitas pada Remaja Siswa SLTP Kota dan Desa di DIY. Jurnal Gizi Klinik Indonesia November 2004; 1(2): 77-85 
2. Sjarif DR. Childhood Obesity: Evaluation and Management. Naskah Lengkap National Obesity Symposium II; 2003; Surabaya, Indonesia.

3. WHO. Obesity: Preventing and Managing The Global Epidemic. Geneva: WHO Technical Report Series 894; 2000.

4. Hadi H. Beban Ganda Masalah Gizi dan Implikasinya terhadap Kebijakan Pembangunan Kesehatan Nasional. Pidato Pengukuhan Jabatan Guru Besar FK UGM. 2005.

5. Departeman Kesehatan RI. Rencana Pembangunan Kesehatan Menuju Indonesia Sehat 2010. Jakarta: Depkes Rl; 1999.

6. Rosenbaum M, Leibel RL. The Physiology of Body Weight Regulation: Relevance to the Etiology of Obesity in Children. Prediatric 1998;101:525-39.

7. Dietz WH. Use Of The Body Mass Index (BMI) As A Measure of Overweight in Children and Adolescents. J Pediatr 1998;132:191-3.

8. Taitz LS. Textbook of Pediatric Nutrition. $3^{\text {rd }}$ ed. In: McLaren DS, Burman D, Belton NR, Williams AF, editors. Obesity. London: Churchill Livingstone; 1991. p.485-509.

9. Pi-Sunver FX. Modern Nutrition In Health and Disease. $8^{\text {th }}$ ed. In: Shils ME, Olson JA, Shike M, editors. Obesity. Tokyo: Lea \& Febiger; 1994. p. 984-1006..

10. Wang Y, Monteiro C, and Popkin BM. Trend of Obesity and Underweight in Older Children and Adolescents in the United States, Brazil, China, and Rusia. Am J Clin Nutr 2002;75:971-7.
11. Yap MA, and Tan WL. Faktor Associated with Obesity in Primary-school Children in Singapore. Asia Pacific J Clin Nutr 1994;65-8.

12. Herini ES, Ismail $D$, Hagung $P$, and Sadjimin T. Fast Food Consumption and Obesity: Relationship among Elementary School Studens in Yogyakarta. Paediatrica Indonesiana 1999;39:127-33.

13. Suhendro. Fast Food sebagai Faktor Risiko Terjadinya Obesitas pada Remaja Siswa-siswi SMU di Kota Tangerang Propinsi Banten [tesis]. Jogjakarta: Program Pascasarjana Universitas Gadjah Mada; 2003.

14. Nasar SS. Obesitas pada Anak: Aspek Klinis dan Pencegahan. Naskah Lengkap Pendidikan Kedokteran Berkelanjutan IImu Kesehatan Anak, XXXV; 1995; Jakarta, Indonesia.

15. Satoto, Karjati S, Darmojo B, Tjokroprawiro A, Kodyat BA. Kegemukan, Obesitas dan Penyakit Degeneratif: Epidemiologi dan Strategi Penanggulangannya. Widyakarya Nasional Pangan dan Gizi. Jakarta: LIPI; 1996.

16. Heird WC. Parental Feeding Behavior and Children's Fat Mass. Am J Clin Nutr 2002;75:451-2.

17. Sjarif DR. Childhood Obesity: Evaluation and Management. Naskah Lengkap National Obesity Symposium II; 2002; Surabaya, Indonesia.

18. Dietz WH. Critical Periods in Childhood for The Development of Obesity. Am J Clin Nutr 1994;59:955-9. 